\title{
Hepatitis C virus in Egypt: is more than one challenge
}

\section{Opinion}

Hepatitis $\mathrm{C}$ virus $(\mathrm{HCV})$ has great genetic variability, with 6 major genotypes (GTs); GT-1 to $6 .{ }^{1}$ In Egypt, HCV is almost exclusive GT-4 distribution. ${ }^{2} \mathrm{HCV}$ has significant differences in their global distribution and prevalence. ${ }^{3} \mathrm{HCV}$ is a worldwide infection, it is estimated that about $3.0 \%(170-200$ million people $)$ of the world's population are infected. HCV is associated with an increased disease burden due to liver cirrhosis and considerable mortality. ${ }^{4}$ More than 350,000 people dying each year from hepatitis C-related liver disease. ${ }^{2}$ Adding to the problem of $\mathrm{HCV}$ infection is the presence of occult HCV infection. ${ }^{5,6}$

Egypt has the highest prevalence worldwide 7,8 it is estimated to be $14.7 \%$ among a representative sample of Egyptian population, aged 15-59year. ${ }^{9}$ Egypt is among countries responsible for $80.0 \%$ of global infections, further it is rank 4 th. ${ }^{10}$ Further, prevalence is higher among hospitalized patients and special clinical populations. ${ }^{6,7}$

In Egypt, $\mathrm{HCV}$ infection is a major, serious public health problem associated with increased morbidity and mortality. ${ }^{9}$ It can lead to the development of cirrhosis and hepatocellular carcinoma. ${ }^{11}$ Unparalleled level of exposure to this infection appears to reflect a national epidemic. It has been postulated that HCV epidemic has been caused by an extensive iatrogenic transmission during the era of parenteral antischistosomal therapy (PAT) mass treatment campaigns. ${ }^{12}$ Today, $\mathrm{HCV}$ infection and its complications are among the leading public health challenges in Egypt. ${ }^{13}$

The most common HCV infection risk factors in Egypt are increasing age, a history of PAT, and residing in rural areas. ${ }^{14,15}$ Other common risk factors were related to health care settings as history of blood transfusions, invasive procedures, injections, hemodialysis (HD), and dental work. ${ }^{6,15-19}$ Community and informal health provider related exposures as circumcision, and cautery were also associated with HCV infection. ${ }^{15,20}$

Early (2001) in 20th century the Ministry of Health in Egypt initiated broad Infection Control Programs all over the country. ${ }^{21}$ So, this year was considered as a cut-off year for controlling infections caused by all means of micro-organisms transmission at all health facilities in Egypt. ${ }^{13}$

Different HCV studies conducted among diverse subgroups of general population, consistently report a very high $\mathrm{HCV}$ prevalence. Further, overall prevalence in rural areas averaged about $20.0 \%$, higher than the national average..$^{13}$ El-Ahmady et al. ${ }^{22}$ found $20.0 \%$. Recently, El-Moselhy et al. ${ }^{6}$ reported $61.3 \%$ prevalence of $\mathrm{HCV}$ infection among HD patients in Egypt. Also, among blood donors, a higher prevalence was observed among paid blood donors compared to voluntary donors. ${ }^{22,23}$ Male blood donors and blood donors from rural areas had a higher prevalence than their female counterparts ${ }^{24}$ and than those from urban areas. ${ }^{25}$ Further, among acute viral hepatitis patients, HCV prevalence was $4.3 \%{ }^{26}$ to $78.7 \%,{ }^{27}$ with higher prevalence among those resident in rural areas compared to urban ones. Furthermore, the average $\mathrm{HCV}$ prevalence among schistosomiasis patients was about

\author{
Volume 3 Issue 3 - 2017
}

\author{
Eessam A. El-Moselhy \\ Head Department of Public Health and Community Medicine, \\ Al-Azhar University, Egypt
}

\author{
Correspondence: Eessam A. El-Moselhy, Professor of \\ Epidemiology, Head Department of Public Health and \\ Community Medicine, Faculty of Medicine,Al-Azhar University, \\ Egypt, Email dr.elmoselhy@azhar.edu.eg
}

Received: February 27, 2017| Published: June 15, 2017

$38 \%$. Also, El-Sabah et al. ${ }^{28}$ reported a prevalence of $84.0 \%$ among schistosomiasis patients treated with PAT 20 to 30years ago and a prevalence of $7.7 \%$ among those patients recently treated using oral method. In Egypt, a study was conducted among intravenous drug users revealed $63.0 \%$ prevalence of $\mathrm{HCV} .{ }^{29}$ High $\mathrm{HCV}$ prevalence was also observed among pregnant women and children in Egypt, a prevalence of $\sim 8.0 \%$ in Benha $^{30}$ and $15.8 \%$ in rural villages of the Nile Delta. ${ }^{14}$

In Egypt treatment of HCV patients started since decades. The goal of $\mathrm{HCV}$ therapeutic is to achieve a sustained virological response. ${ }^{2}$ In late 2015, HCV therapy with Sofosbuvir was launched in Egypt by Ministry of Health and the Egyptian National HCV Control Program. There are several challenges in combating HCV infection; drug regimen is expensive and cost, lose applied infection control, socioeconomic and demographic characters of the community are obstacles, and up to 200,000 patients are estimated to be infected each year. So, Egypt needs more support at the national and international levels. During her visit to Cairo, WHO director general Margret Chan recognized Egypt's efforts in the treatment of Hepatitis C. ${ }^{31}$ Two days ago, Messi (the famous football player) visited Egypt in February 21, 2017 to promote hepatitis C therapy. ${ }^{32}$ Lastly, new surveillance program should be applied for sustained prevention and control of HCV infection and its complications in Egypt.

\section{Acknowledgements}

None.

\section{Conflict of interest}

Author declares that there is no conflict of interest.

\section{References}

1. Simmonds P, Bukh J, Combet C, et al. Consensus proposals for a unified system of nomenclature of hepatitis $\mathrm{C}$ virus genotypes. Hepatology. 2005;42(4):962-973.

2. Wartelle-Bladou C, Le Folgoc G, Bourlière M, et al. Hepatitis C therapy in non-genotype 1 patients: The near future. $J$ Viral Hepat. 2012;19(8):525-536

3. Bostan N, Mahmood T. An overview about hepatitis C: A devastating virus. Crit Rev Microbiol. 2010;36(2):91-133. 
4. Yen T, Keeffe EB, Ahmed A. The epidemiology of hepatitis C virus infection. J Clin Gastroenterol. 2003;36(1):47-53.

5. Barril G, Castillo I, Arenas MD, et al. Occult hepatitis C virus infection among hemodialysis patients. $J$ Am Soc Nephrol. 2008;19(12):2288-2292.

6. El-Moselhy EA, Abd El-Aziz A, Atlam SA. Prevalence and risk factors of overt- and occult hepatitis $\mathrm{C}$ virus infection among chronic kidney disease patients under regular hemodialysis in Egypt. Egypt $J$ Hosp Med. 2015;61:653-69.

7. Frank C, Mohamed MK, Strickland GT, et al. The role of parenteral anti-schistosomal therapy in the spread of hepatitis $\mathrm{C}$ virus in Egypt. Lancet. 2000;355(9207):887-891.

8. Lavanchy D. Evolving epidemiology of hepatitis C virus. Clin Microbiol Infect. 2011;17(2):107-115.

9. El-Zanaty F, Way A. Egypt demographic and health survey 2008. Ministry of Health, El-Zanaty and Associates, Macro International Cairo, Egypt; 2009.

10. Gower E, Estes C, Blach S, et al. Global epidemiology and genotype distribution of the hepatitis C virus. J Hepatol. 2014;61(1 Suppl):S45-S57.

11. Moyer VA. Screening for hepatitis $\mathrm{C}$ virus infection in adults: US preventives services task force recommendation statement. Ann Intern Med. 2013;159:349-357.

12. Strickland GT. Liver disease in Egypt: hepatitis C superseded schistosomiasis as a result of iatrogenic and biological factors. Hepatology. 2006;43(5):915-922.

13. Mohamoud YA, Mumtaz GR, Riome S, et al. The epidemiology of hepatitis $\mathrm{C}$ virus in Egypt: A systematic review and data synthesis. BMC Infect Dis. 2013;13:288.

14. Stoszek SK, Abdel-Hamid M, Narooz S, et al. Prevalence of and risk factors for hepatitis $\mathrm{C}$ in rural pregnant Egyptian women. Trans $R$ Soc Trop Med Hyg. 2006;100(2):102-107.

15. Arafa N, El Hoseiny M, Rekacewicz C, et al. Changing pattern of hepatitis $\mathrm{C}$ virus spread in rural areas of Egypt. J Hepatol. 2005;43(3):418-424.

16. Saleh DA, Shebl F, Abdel-Hamid M, et al. Incidence and risk factors for hepatitis $\mathrm{C}$ infection in a cohort of women in rural Egypt. Trans $R$ Soc Trop Med Hyg. 2008;102(9):921-928.

17. El-Sadawy M, Ragab H, El-Toukhy H, et al. Hepatitis C virus infection at Sharkia Governorate, Egypt: seroprevalence and associated risk factors. J Egypt Soc Parasitol. 2004;34(1):367-384.

18. Mohamed MK, Hussein MH, Massoud AA, et al. Study of the risk factors for viral hepatitis $\mathrm{C}$ infection among Egyptians applying for work abroad. J Egypt Public Health Assoc. 1996;71(1-2):113-147.
19. Kalil KA, Farghally HS, Hassanein KM, et al. Hepatitis C virus infection among paediatric patients attending University of Assiut Hospital, Egypt. East Mediterr Health J. 2010;16(4):356-361.

20. Medhat A, Shehata M, Magder LS, et al. Hepatitis C in a community in Upper Egypt: risk factors for infection. Am J Trop Med Hyg 2002;66(5):633-638.

21. Talaat M, Kandeel A, Rasslan O, et al. Evolution of infection control in Egypt: Achievements and challenges. Am J Infect Control. 2006;34(4):193-200.

22. El-Ahmady O, Halim AB, Mansour O, et al. Incidence of hepatitis C virus in Egyptians. J Hepatol. 1994;21(4):687.

23. Eita N. Prevalence of HCV and HBV infections among blood donors in Dakahilia, Egypt. Vox Sang. 2009;96:106-107.

24. Rushdy O, Moftah F, Zakareya S. Canal Trasmitted transfused viral infections among blood donors during years 2006 and 2007 in Suez area, Egypt. Vox Sang. 2009;96:86-87.

25. Arthur RR, Hassan NF, Abdallah MY, et al. Hepatitis C antibody prevalence in blood donors in different governorates in Egypt. Trans R Soc Trop Med Hyg. 1997;91(3):271-274.

26. Eldin SS, Seddik I, Daef EA, et al. Risk factors and immune response to hepatitis E viral infection among acute hepatitis patients in Assiut, Egypt. Egypt J Immunol. 2010;17(1):73-86.

27. Meky FA, Stoszek SK, Abdel-Hamid M, et al. Active surveillance for acute viral hepatitis in rural villages in the Nile Delta. Clin Infect Dis. 2006;42(5):628-633

28. El-Sabah AA, El-Metwally MT, Abozinadah NY. Hepatitis C and B virus in schistosomiasis patients on oral or parenteral treatment. $J$ Egypt Soc Parasitol. 2011;41(2):307-314

29. El-Ghazzawi E1, Drew L, Hamdy L, et al. Intravenous drug addicts: a high risk group for infection with human immunodeficiency virus, hepatitis viruses, cytomegalo-virus and bacterial infections in Alexandria Egypt. $J$ Egypt Public Health Assoc. $1995 ; 70(1-2): 127-150$

30. AbdulQawi K1, Youssef A, Metwally MA, et al. Prospective study of prevalence and risk factors for hepatitis $\mathrm{C}$ in pregnant Egyptian women and its transmission to their infants. Croat Med J. 2010;51(3):219-228.

31. Khater M. WHO recognizes Egypt's efforts in the combating Hepatitis C. Daily News Egypt. 2016.

32. El-Nadar M. Messi visits Egypt to promote hepatitis C treatment Daily News Egypt. 2017. 